\title{
Characteristics and issues of rural tourism in Japan
}

\author{
Y. Ohe \\ Department of Food and Resource Economics, Chiba University, Japan
}

\begin{abstract}
While rural tourism will provide new opportunities for farmers and inhabitants in rural areas, many problems must be solved to make the sustainable development of tourism a reality. Therefore, this paper focused on the present issues facing rural tourism in Japan that must be addressed for further development. Firstly, we characterized rural tourism in Japan as still being in transition from the old style rural tourism that has been conducted as a low quality sideline for farmers in winter to modern rural tourism that provides tourists with a better quality experience and authentic rural hospitality. The main reason that this transition is not yet complete is because institutional constraints on a long-holiday system remain and thus farmers must rely on day-trippers rather than overnight tourists. Secondly, we pointed out the generation gap between the young and middle/senior generations in terms of recognition of the value of rural tourism as well as experience with rural tourism, and also the mismatch between the rural and urban sides in terms of desires and expectations. The urban side wants more software aspects such as information on available menus and where to find rural tourism accommodation and sites of interest, while the rural side tends to look at hardware aspects such as building facilities for tourists. Thus, it is crucial to properly recognize the existence of the mismatch between the two sides. This is the first step in rectifying the causes of the mismatch and enables farmers to offer proper services to meet the growing demand.
\end{abstract}

Keywords: rural tourism, authentic rural hospitality, sustainable rural development, mismatch between rural and urban sides, farm diversification.

\section{Introduction}

Rural tourism has been advocated as an effective means of farm diversification (Haines and Davies [2], Slee [15]) and has been studied from the viewpoint of 
farm-based rural hospitality businesses in many countries (Page and Getz [13]). These studies have contributed to progress in rural tourism research and policy design for the promotion of rural tourism. Rural tourism requires us to rediscover values of local resources neglected in the modernization process of the national economy and to educate both farmers and policymakers to adopt a wider perspective than the hitherto agro-centric mentality. However, discussions on rural tourism have tended to be made from the Western perspective (For recent topics on rural tourism, see for example Hall et al. [3, 4]. For Japanese studies, Ohe [7] examined behaviours of farmhouse accommodation operators in connection with farming production. Ohe [11] studied women's role for rural tourism. For introductory studies on gender issues in rural Japan, see Tsutsumi [16]. Ohe [12] deals with the roles of retiree farmers in rural tourism activity and Ohe [10] evaluated an impact of rural road building on rural tourism.) and are often ad hoc due to the multidisciplinary nature of this issue. From our viewpoint, it is time to discuss rural tourism from the Japanese perspective on the one hand and to generalize the significance, problems and prospects under a coherent perspective on the other. These efforts are necessary for the desirable dissemination of the Asian type of rural tourism that has distinctive features that differ from traditional farm activity and the Western situation.

Thus, we firstly examine the conceptual characteristics of rural tourism in comparison with ordinary farm products from the farm diversification perspective. Secondly, we review the current situation of rural tourism in Japan as a case study and estimate the market size of rural tourism in this country. Thirdly, problems and constraints of rural tourism are discussed and, finally, policy implications for the future development of rural tourism are mentioned.

\section{Conceptual considerations: framework for emerging rural markets}

The recent surge of rural tourism and direct selling by farmers from stands or shops in rural areas creates a new possibility for forming other markets as well as markets for farm products that exist only in the city.

Figure 1 illustrates that in addition to the traditional route of farm products from rural areas to urban markets depicted by the arrow from left to right another arrow emerges from right to left. This arrow emerges because urban dwellers have begun to exhibit purchasing behaviour for farm products that often has the features of service goods such as rural tourism.

Therefore, we assume that there are two spatially segregated markets in rural and urban areas, and these are termed here "urban markets" and "rural markets", respectively. This is because prices for traditional farm products are formed in urban markets, while prices for rural tourism are formed in rural markets. In other words, the difference is based on whether or not price formation is done at the point of production. This is why we should consider two spatially independent markets. Profiles of the two products, which we call "rural tourism goods" and "ordinary farm products," are characterized and contrasted in Table 1. The profiles show two different goods dealt in spatially different markets. 


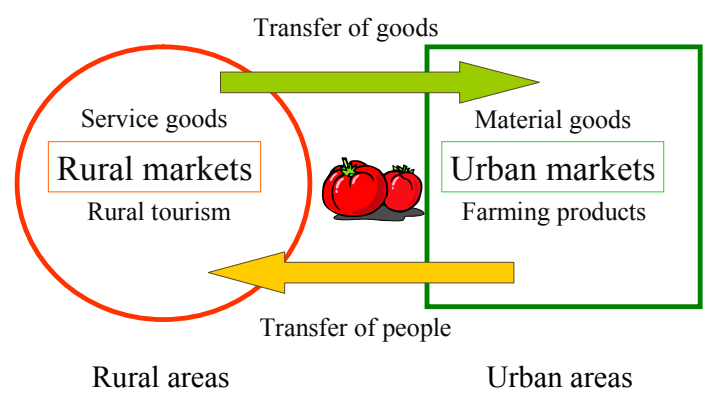

Figure 1: Rural-urban relationship with two products.

Table 1: $\quad$ Comparison of two different farm goods.

\begin{tabular}{|c|c|c|}
\hline Characteristics & Rural tourism goods & Ordinary farming products \\
\hline Location of markets & Rural areas & Urban areas \\
\hline Who pays transportation costs & Consumers (visitors) & Producers \\
\hline Types of demand & $\begin{array}{c}\text { Recreation, purchase of } \\
\text { local foods }\end{array}$ & Food purchase \\
\hline Types of goods & Service goods & Physical goods \\
\hline Types of market & Niche, up-market & Mass Market \\
\hline $\begin{array}{c}\text { Possibility of internalizing } \\
\text { multifucntionality into farm activity }\end{array}$ & Positive & Neutral \\
\hline
\end{tabular}

In the case of the urban market, ordinary farm products are traditionally shipped to urban markets for consumption. Generally, these products are for a mass market utilizing a mass distribution system conducted by retailers or agricultural cooperatives. Transportation costs are usually borne by producers.

Conversely, in the case of rural markets, products are demanded mainly by urban habitants and partially by rural habitants. The following are included in the category of rural tourism goods: accommodations, rural cuisine, farm and farming experiences, pick-your-own, etc. These have some of the characteristics of service goods. Further, farmers' shops and products ordered by telephone or email and delivered through the postal service or other carriers are also included in this category. Products sold in this manner are considered to be purchased by urban consumers who pay transportation costs. (In taking into account of transportation cost, in the case of rural tourism goods the demand curve will shift leftward while in the case of ordinary farm products the supply curve will shift leftward. The detailed conceptual comparison of the two markets within a microeconomics framework was fully conducted in Ohe [9]. However, no empirical study was conducted.) A common factor among these products is that those who demand these goods pay the costs of coming to the rural markets or the delivery costs.

The market size for rural tourism goods is not large, and these markets are considered to be niche markets, as is often pointed out (OECD [5, 6]). Thus, it is 
assumed that these characteristics result in larger income elasticity of demand compared with that of ordinary farm products such as food.

In connection with multifunctionality of agriculture, the positive externality generated by farming activity can be internalized as rural tourism activity by farmers. In this sense rural tourism can realize income by internalizing the externality generated as multifunctionality. On the contrary, ordinary farm products can create multifunctionality, although they are considered to be neutral for utilizing multifunctionality by internalization into farming activity.

It is supposed that these two markets are not substitutable, but are complementary to each other for farmers. When we take into account the two possible markets, it is easier to extend perspectives towards farm diversification.

\section{Rural tourism in transition}

Now we examine the present situation of rural tourism in Japan. The Ministry of Agriculture, Forestry and Fisheries (MAFFJ) began the "green tourism" program in 1993. "The law for promotion of holiday in rural areas" that aims to promote green tourism was in effect in 1995. Under the framework of this law, green tourism farms that offer accommodation and can provide farm experience services in farming, forestry or fishing are registered. Table 2 elucidates the number of registered green tourism farms in the each area. Area-wise, the Kanto and the Hokuriku area that includes the Tokyo capital sphere has the two largest number of green tourism farms because there have been traditionally many farmhouse accommodations that have provided accommodation service for skiers in winter in the prefecture of Nagano, a mountainous region in the central Japan, and these farms have been registered as green tourism farms since the law was enacted.

Table 2: Number of designated green tourism (GT) farms (as of end of March, 2006).

\begin{tabular}{|c|c|c|c|c|c|c|c|c|c|c|}
\hline Area & Hokuriku & Kanto & Tohoku & Tokai & Kinki & Kyusyu & \begin{tabular}{|c} 
Chugoku/ \\
Shikoku \\
\end{tabular} & Hokkaido & Okinawa & Total \\
\hline No. GT & 166 & 159 & 77 & 37 & 31 & 28 & 22 & 16 & 3 & 539 \\
\hline farms & $(30.8)$ & $(29.5)$ & $(14.3)$ & $(6.9)$ & $(5.8)$ & $(5.2)$ & (4.1) & $(3.0)$ & $(0.6)$ & $(100.0)$ \\
\hline
\end{tabular}

Source: The Organization for Urban-Rural Interchange Revitalization, 2006.

In focusing on accommodation activity, we contrasted tourism activity by farmers into two types: the old type and the new type. Table 3 compares the main characteristics of the two. We call the new type "rural tourism."

The old type of tourism activity had been conducted by farmers for years in Western Europe and Japan before rural tourism started. A typical example is that farmhouse accommodation was performed as an auxiliary business during the slack farming period in winter. This old type of activity often is performed around ski resort areas in Nagano as already mentioned. The main aim of visitors is not to stay at a farm, but to do non-farm related things such as skiing in winter or hiking in summer. Therefore, the demand for a farm stay is a derivative or secondary one. For this reason, visitors do not expect a high level of service quality and are satisfied with cheap service. As a result, farmers do not have an 
incentive to improve quality. In that market, mainly low-income people constitute demand and the quality of products is low and is termed as a "downmarket." Many traditional farmhouse accommodations remain at this stage in Japan but are losing visitors due to inability to cope with the new needs of visitors.

On the contrary, rural tourism or green tourism in Japan is at another stage. At this stage, farmers newly reconfigure traditional tourism services and provide new services that meet current needs of society. Farmers offer not only accommodation services, but also full-fledged service goods, taking advantage of tangible and intangible rural goods such as rural amenities, heritage, local food culture and farm products. The demand for these new services, therefore, is not secondary, but becomes original in the sense that people primarily come to visit the countryside and to stay on the farm.

Table 3: $\quad$ Comparison of old and new tourism.

\begin{tabular}{ccc}
\hline Features & Old type & New type \\
\hline \multirow{2}{*}{ Supply side } & Part-time & Full-time \\
& Utilization of idle facility & Utilization of \\
& and labour & multifunctionality \\
& Low quality of service & High quality of service \\
Demand side & Derivative & High level of management skill \\
\hline Market & Low level of needs & Original \\
\hline Example & Down market & High level of needs \\
\hline
\end{tabular}

Those with such demands are understood to be in the middle class in Western Europe (Sharpley [14]). The commonality in this respect is confirmed also in Japan (Ohe [8]). We can characterize this market for rural tourism as up-market," which means that those of high academic background and therefore of high income who request higher quality service products mainly constitute the demand. Hence, the quality of services becomes more important than that of the former type.

Whereas we contrasted the two types here, the old and the new are not totally isolated from each other in effect. Actually, quite a few areas have been successfully transformed from the old to the new. It will be possible for old areas to transform to the new type if demand for these services matures and the operator's skill can catch up to demand. In this context, we consider that green tourism in Japan is characterized as, firstly, at the transition stage on the way to the new from the old type and, secondly, it takes longer time for this transition.

Nonetheless, for a smooth transition, it is necessary to consider peculiar features of Japanese and Asian circumstances, as mentioned below, which differ from those in Western Europe. 


\section{How large is the market for rural tourism?}

It has been noted that rural tourism is not a mass market but a niche market. Nonetheless, except for ad hoc surveys, there is not yet a periodic government statistical survey on rural tourism nor an established method of estimating market size. Thus, we roughly estimated market size. Table 4 shows that the results of an estimation of the rural tourism market size performed by a team, of which the author was a part. A questionnaire survey was conducted by this team in 2002 and administered to the section in charge of rural tourism in 47 prefectures. Data obtained were used for the estimation. Several estimates were performed from two different approaches: the supply side and the demand side. Results for the supply side are shown in the left side of Table 4, in which there is variation from 401.9 to 598.4 billion yen (equal to $\$ 3.6$ to $\$ 5.3$ billion).

Table 4: $\quad$ Results of estimation of rural tourism market size.

\begin{tabular}{|c|c|c|c|c|}
\hline \multicolumn{3}{|c|}{$\begin{array}{l}\text { Supply side estimate of } \\
\text { gross sales }\end{array}$} & \multicolumn{2}{|c|}{$\begin{array}{l}\text { Demand side estimate of } \\
\text { consumption }\end{array}$} \\
\hline $\begin{array}{c}\text { Estimate from } \\
\text { sample } \\
\text { average }\end{array}$ & $\begin{array}{l}\text { Estimate from } \\
\text { sample average } \\
\text { without outlier }\end{array}$ & $\begin{array}{l}\text { Regression } \\
\text { estimate }\end{array}$ & $\begin{array}{l}\text { Consumption } \\
\text { estimate } 1\end{array}$ & $\begin{array}{c}\text { Consumption } \\
\text { estimate } 2\end{array}$ \\
\hline $\begin{array}{l}¥ 598.4 \text { billion } \\
\text { ( } \$ 5.3 \text { billion) }\end{array}$ & $\begin{array}{l}¥ 450.1 \text { billion } \\
(\$ 3.9 \text { billion })\end{array}$ & $\begin{array}{l}¥ 401.9 \text { billion } \\
\text { (\$3.6 billion ) }\end{array}$ & $\begin{array}{l}¥ 969.5 \text { billion } \\
(\$ 8.6 \text { billion })\end{array}$ & $\begin{array}{l}¥ 861.3 \text { billion } \\
(\$ 7.6 \text { billion })\end{array}$ \\
\hline
\end{tabular}

Source: The Organization for Urban-Rural Interchange Revitalization, 2002.

Note: 1 . Value in US $\$$ was calculated by $\$ 1=¥ 113$.

2. Consumption estimate 1 includes travel cost and consumption at local site.

3. Consumption estimate 2 includes travel cost and consumption at farm shop.

These estimates were for gross revenue or the direct economic effect without considering the indirect economic impact on the local economy. It cannot be denied that there are activities that are only partially grasped.

Results of the estimates from the demand side are shown on the right side of the table, and were 861.3 and 969.5 billion yen ( $\$ 7.6$ and $\$ 9.8$ billion, respectively), which is roughly twice that of the supply side estimates. This is because the indirect economic impact is included in the second estimation. In considering the insufficient coverage by the survey on all rural tourism activities since the survey was still in the initial stage, it is probable that the actual size of rural tourism will reach roughly 1 trillion yen. We can say that the value is about the size of a niche market because it is much smaller than that of agricultural production, i.e. 9 trillion yen. It should be noted that the rural tourism market will increase in the future. The important point here is that the market size of rural tourism will grow while conventional agricultural production will remain stagnant. 


\section{The issues of rural tourism in Japan}

\subsection{Institutional aspects}

Here, we examine the direction that we should take for the development of rural tourism. Figure 2 conceptually illustrates the demand shift of accommodation services measuring the unit of tourists vertically and duration of stay horizontally. The square by-product of the two factors expresses the size of demand. The unit of travel most often used in the past was performed by a group of people rather than by a family when income was generally low. The unit of travel tends to be large since a trip by a group of friends or colleagues more commonly was undertaken than by an individual and the duration of stay was short, being one or two nights. As a result, the square aoej produced by the two factors takes a long shape vertically. This case is the pattern of the old type of tourism that was observed during the period of high economic growth in this country. This is one reason why the average capacity of farmhouse accommodation in Japan tends to be larger than that in Europe.

Nonetheless, when people begin to take longer trips after economic development, travel behaviour will change to what is usual in Western Europe. The tourist unit will be smaller because families and young, middle age or empty nest senior couples will be common. On the other hand, stays will be of longer duration. Then the demand for rural tourism will increase to the square bofi that takes a long shape horizontally. To simplify the discussion we postulate that these changes occur along with the line $m n$. When the tourist unit becomes smaller and the duration of stay becomes longer, these changes are translated in the downward shift on the line $m n$ and the demand will increase.

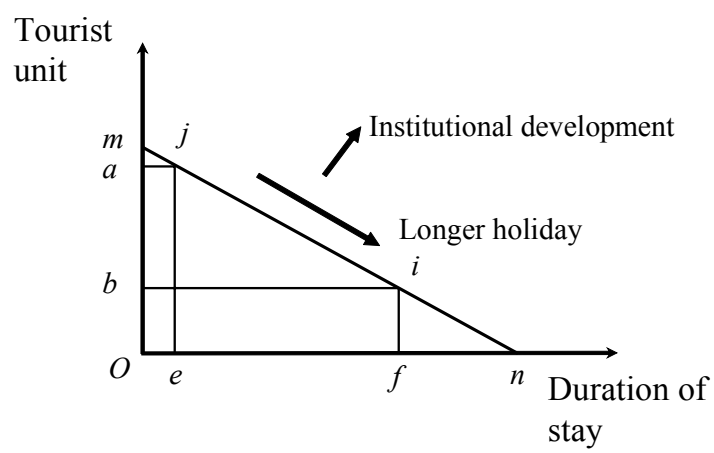

Figure 2: Pattern of the tourist unit and duration of stay.

Furthermore, the line should shift to the right upward direction in order to attain a substantial increase in demand in the long term. To this aim, the long paid holiday program that has been implemented in Western Europe should be institutionalized because this program generates demand for long stays and less expensive accommodations, which provides opportunities for rural tourism. This institutionalization, however, is not yet completed in Japan. This is an institutional constraint unlike the situation in Western Europe. 
Another point that is partly connected with the first institutional constraint regarding a long holiday is that the demand for rural tourism has not yet fully matured to become part of the life style of urban habitants. Table 5 shows awareness of rural tourism in Japan according to age in decades. On average, only less than half of respondents knew what rural tourism means although interest is growing steadily and gradually. With regard to age group, the younger the group, the lower the portion of those who knew what rural tourism is; recognition was about $30 \%$ among those in their 20 s, about $40 \%$ among those in their 30 s and $40 \mathrm{~s}$ and more than $50 \%$ of those in their 50 s and beyond. Another question was related to actual experience with rural tourism.

In Table 6 two categories of tourists are described: overnight tourists and daytrippers. Whereas $70 \%$ of overnight tourists and nearly $60 \%$ of day-trippers did not experience rural tourism, there was an apparent difference among age groups. The younger the age group, the lower the percentage having experienced rural tourism.

Table 5: $\quad$ Degree of recognition of rural tourism (\%).

\begin{tabular}{|c|c|c|c|c|c|}
\hline Age group & Total & $\begin{array}{c}\text { Know } \\
\text { what it is }\end{array}$ & $\begin{array}{c}\text { Heard but do } \\
\text { not know } \\
\text { what it is }\end{array}$ & $\begin{array}{c}\text { Never } \\
\text { heard }\end{array}$ & $\begin{array}{c}\text { No } \\
\text { answer }\end{array}$ \\
\hline Average & 100 & 46.1 & 27.9 & 25.6 & 0.4 \\
\hline $20 \mathrm{~s}$ & 100 & 29.4 & 22.4 & 47.1 & 1.2 \\
\hline $30 \mathrm{~s}$ & 100 & 41.5 & 27.0 & 31.5 & - \\
\hline $40 \mathrm{~s}$ & 100 & 39.8 & 30.5 & 29.7 & - \\
\hline $50 \mathrm{~s}$ & 100 & 60.2 & 23.6 & 16.2 & - \\
\hline over 60s & 100 & 50.7 & 32.3 & 15.7 & 1.3 \\
\hline
\end{tabular}

Source: Agriculture, Forestry and Fishery Pocket Statistics, 2004 MAFFJ.

Table 6: $\quad$ Percentage of those who experienced rural tourism (\%).

\begin{tabular}{|c|c|c|c|c|c|}
\hline Type & Age group & Total & No & Yes & No answer \\
\hline & Average & 100 & 70.0 & 23.8 & 6.2 \\
\hline overnight & $20 \mathrm{~s}$ & 100 & 81.2 & 15.3 & 3.5 \\
\hline stay & $30 \mathrm{~s}$ & 100 & 76.3 & 20.8 & 2.9 \\
& $40 \mathrm{~s}$ & 100 & 72.0 & 23.1 & 4.9 \\
\hline & $50 \mathrm{~s}$ & 100 & 69.0 & 24.5 & 6.5 \\
\hline & over 60s & 100 & 57.8 & 30.1 & 12.1 \\
\hline \multirow{3}{*}{ daytrip } & Average & 100 & 57.8 & 37.8 & 4.4 \\
\hline & $20 \mathrm{~s}$ & 100 & 68.2 & 29.3 & 4.7 \\
\hline & $30 \mathrm{~s}$ & 100 & 63.9 & 32.8 & 2.5 \\
\hline & $40 \mathrm{~s}$ & 100 & 61.0 & 35.2 & 3.3 \\
\hline & $50 \mathrm{~s}$ & 100 & 54.2 & 37.7 & 3.7 \\
\hline & over 60s & 100 & 47.1 & 44.8 & 8.1 \\
\hline
\end{tabular}

Source: Agriculture, Forestry and Fishery Pocket Statistics, 2004 MAFFJ. 


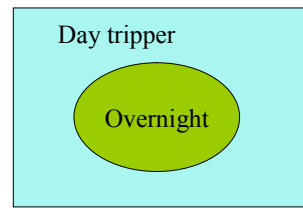

Western Europe

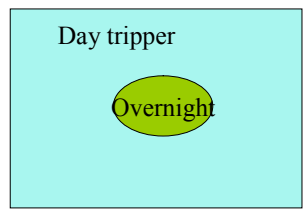

Japan

Figure 3: Demand type of rural tourism.

In short, there are obvious differences among age groups in interest and experience in relation to rural tourism. Therefore, it is important to let the young know more about rural tourism through the IT methodology that they are familiar with and frequently use.

It can hardly be denied that these factors work against the development of rural tourism. These challenges, however, do not always mean that we should be pessimistic for the future of rural tourism in this country and in Asian countries. Rather we should understand that these are initial conditions that must be accepted and used as the basis of development of rural tourism.

For this reason, in the short- and mid-term, an increase in the number of visitors and in the length of stay cannot be expected to become a reality. Therefore, operators of rural tourism should count on not only overnight tourists, but also day-trippers, especially when the farms are in the vicinity of urban areas within daytrip distance.

Here, we contrast the difference in characteristics of visitors between Japan (right) and Western Europe (left) in Figure 3. To simplify the discussion, the area of the square is assumed as the market size of rural tourism and the areas are the same between the two. The oval shape is the market size of overnight tourists and the remaining portion is the market size of day-trippers. As can be easily recognized, the demand for overnight stays in the Japanese case is smaller while the demand for daytrips is larger than in Western Europe. Therefore, it is necessary to expand the demand not only for overnight stays, but also for daytrips for stable development of rural tourism in this country. This relatively small demand size for overnight stays is considered not only a Japanese but also an Asian characteristic of rural tourism.

The importance of day-trippers is not only limited to the aspect of demand increase, but also to relieve the seasonality that is unavoidable in every type of tourism activity that includes rural tourism everywhere.

\subsection{Issues of service management}

The distinctive process of service production whereby both production and consumption occur all at once is critical for evaluation of service goods because the impression of visitors is largely determined during this process. Hence, this process is the most crucial moment that decisively impresses the quality of service to customers.

Carlzon [1] called this process "the moment of truth" as the most critical production process for service management. Rural tourism is not an exception 
because activities such as farm experience programs, farm stays, farm restaurants and farm shops always involve the process of interchange between producers and consumers and during this process consumer's evaluation of the quality of provided services are determined. Therefore, what should constitute rural hospitality and how to improve it remain to be explored.

Finally, we discuss topics to be tackled in the future. Officers in municipalities and tourists answered these issues as shown in Tables 7, 8, and 9 respectively. Table 7 and 8 contrasts differences between urban and rural areas. Concerning municipalities, meeting the needs of urban people was the highest among the items; in particular, those in the city wanted the rural side to understand what urban people actually expect from rural tourism. In contrast, those in rural areas selected issues having hardware aspects such as farm experience facilities. The commonality for both sides was the nurturing of human resources such as coordinators and instructors who can work as go-betweens for both sides.

Table 7: $\quad$ Issues on rural tourism development (urban side) (\%).

\begin{tabular}{|c|c|c|c|c|c|c|c|c|}
\hline \multicolumn{7}{|c|}{ Table 7: Issues on rural tourism development (Urban side). } & (\%) \\
\hline Area & $\begin{array}{c}\text { No. of } \\
\text { municipalities }\end{array}$ & Total & $\begin{array}{c}\text { Meeting needs } \\
\text { of urban } \\
\text { people }\end{array}$ & $\begin{array}{c}\text { Cultivation of } \\
\text { advisers/ } \\
\text { coordinators }\end{array}$ & $\begin{array}{c}\text { Imformation } \\
\text { on destination }\end{array}$ & $\begin{array}{c}\text { Trans- } \\
\text { portation }\end{array}$ & $\begin{array}{c}\text { Farm } \\
\text { experience } \\
\text { facility }\end{array}$ & $\begin{array}{c}\text { Accommo- } \\
\text { dation facility }\end{array}$ \\
\hline Urban side & 25 & 100.0 & 44.0 & 28.0 & 12.0 & 8.0 & 4.0 & 4.0 \\
\hline
\end{tabular}

Source: Agriculture, Forestry and Fishery Pocket Statistics, 2004 MAFFJ.

Note: Urban side means Tokyo metropolitan area and designated large cities.

Table 8: $\quad$ Issues on rural tourism development (rural side) (\%).

\begin{tabular}{|c|c|c|c|c|c|c|c|c|c|c|c|}
\hline Area & $\begin{array}{c}\text { No. of } \\
\text { municipalities }\end{array}$ & Total & $\begin{array}{c}\text { Meeting } \\
\text { needs of } \\
\text { urban } \\
\text { people }\end{array}$ & $\begin{array}{c}\text { Farm } \\
\text { experience } \\
\text { menu }\end{array}$ & $\begin{array}{c}\text { Farm } \\
\text { experience } \\
\text { facility }\end{array}$ & $\begin{array}{c}\text { Cultivation of } \\
\text { human resources } \\
\text { such as } \\
\text { instructors }\end{array}$ & $\begin{array}{c}\text { Promotion \& } \\
\text { provision of } \\
\text { local } \\
\text { information }\end{array}$ & $\begin{array}{c}\text { Trans- } \\
\text { portation }\end{array}$ & $\begin{array}{c}\text { Accommo- } \\
\text { dation } \\
\text { facility }\end{array}$ & Others & $\begin{array}{c}\text { No } \\
\text { answer }\end{array}$ \\
\hline Rural side & 2,035 & 100.0 & 22.2 & 19.7 & 17.9 & 17.4 & 9.2 & 5.5 & 5.2 & 2.6 & 0.4 \\
\hline
\end{tabular}

With respect to tourists, they were eager to have guidebooks and information on rural tourism, which indicates that provision of information is insufficient at present (Table 9). Tourists in their 30s wanted lower prices, which suggests that young families with small children represent a potential demand for rural tourism.

To summarize, it will be important to not only actively undertake provision of information and public relations directed toward urban people, but also to improve the local tourist infrastructure such as tourist information offices and provision of appropriate information there. Another issue is connected with development of human resources, i.e. rural hospitality skills and training instructors and coordinators.

Nonetheless, there is actually a perception gap between the people in the two areas. The gap is elucidated in Table 10 where a higher portion of municipalities 
in urban areas than their rural counterparts answered that interchange between the two areas is important, although the situation is more urgent for the rural areas. This is rather unexpected and probably because the average rural area is not yet eager to tackle rural tourism in earnest in spite of a few advanced cases. This fact indicates that there is still much to be done to raise awareness for rural tourism on the rural side.

In summary, in taking into account the unique feature of Japanese and Asian social conditions in relation to a long holiday system, rural tourism should positively aim at day-trippers as well whereas rural tourism in general, not only in Japan but in Europe and other countries, aims at overnight tourists.

Table 9: $\quad$ Needs for rural tourism development (\%).

\begin{tabular}{cccccccccccc}
\hline $\begin{array}{c}\text { Age } \\
\text { group }\end{array}$ & Total & Guidebook & $\begin{array}{c}\text { Low } \\
\text { price }\end{array}$ & $\begin{array}{c}\text { More } \\
\text { information } \\
\text { on rural } \\
\text { tourism }\end{array}$ & $\begin{array}{c}\text { Child } \\
\text { and } \\
\text { senior } \\
\text { friendly }\end{array}$ & $\begin{array}{c}\text { More } \\
\text { informative } \\
\text { at local level }\end{array}$ & $\begin{array}{c}\text { Tourist } \\
\text { information }\end{array}$ & $\begin{array}{c}\text { Explanation } \\
\text { of local } \\
\text { foods \& } \\
\text { recipes }\end{array}$ & $\begin{array}{c}\text { More } \\
\text { instructors }\end{array}$ & & Others \\
answer \\
\hline Average & 100.0 & 27.1 & 18.0 & 16.5 & 13.6 & 11.2 & 5.4 & 3.6 & 2.4 & 1.4 & 0.8 \\
$20 \mathrm{~s}$ & 100.0 & 30.6 & 18.8 & 17.6 & 14.1 & 9.4 & 5.9 & 2.4 & 1.2 & - & - \\
$30 \mathrm{~s}$ & 100.0 & 26.1 & 24.5 & 18.7 & 10.4 & 10.0 & 4.1 & 1.7 & 2.5 & 1.7 & 0.4 \\
$40 \mathrm{~s}$ & 100.0 & 31.3 & 18.7 & 18.3 & 10.6 & 11.0 & 4.9 & 2.0 & 2.0 & 0.8 & 0.4 \\
$50 \mathrm{~s}$ & 100.0 & 25.9 & 14.8 & 14.8 & 13.0 & 13.4 & 5.1 & 6.5 & 2.8 & 1.9 & 1.9 \\
over 60s & 100.0 & 23.3 & 13.0 & 13.5 & 21.1 & 11.2 & 7.6 & 4.9 & 2.7 & 1.8 & 0.9 \\
\hline
\end{tabular}

Table 10: $\quad$ Importance of rural tourism (\%).

\begin{tabular}{|c|c|c|c|c|c|c|}
\hline \multicolumn{1}{|c|}{ Area } & $\begin{array}{c}\text { No. of } \\
\text { responding } \\
\text { municipalities }\end{array}$ & Total & $\begin{array}{c}\text { Important } \\
\text { issue }\end{array}$ & $\begin{array}{c}\text { Will be } \\
\text { important } \\
\text { issue }\end{array}$ & $\begin{array}{c}\text { Will not } \\
\text { be } \\
\text { important }\end{array}$ & $\begin{array}{c}\text { No } \\
\text { answer }\end{array}$ \\
\hline Urban areas & 35 & 100.0 & 60.0 & 25.7 & 14.3 & - \\
\hline Rural areas & 3,149 & 100.0 & 49.0 & 43.4 & 7.2 & 0.4 \\
\hline
\end{tabular}

Source: Agriculture, Forestry and Fishery Pocket Statistics, 2004 MAFFJ.

Note: Urban side means Tokyo metropolitan area and designated large cities.

\section{Conclusions}

This paper proposed a conceptual framework to extend our perspective toward rural tourism and discussed significance, characteristics and problems of rural tourism.

From a Japanese or an Asian perspective, it should be noted that there are many problems and constraints to be tackled not only from the aspect of management skills focusing on hospitality and service management, but also from the aspect of the institutional framework over the long term. In this sense, rural tourism is not a panacea for rural development as often said. At the same time there is no doubt that rural tourism will surely contribute to realizing a wellbalanced rural society based on an open and interchangeable rural-urban relationship through exploring new roles for agriculture. In this context, rural tourism is significant not only from economic aspects, but from social aspects. 
To this aim, among other things, the rural side should widen their perspective from the standpoint of local resource management including farming through wider network with urban people. This is the first step in rural tourism. For policy measures, firstly, official and periodical surveys on rural tourism should be established to reveal what actually happens in rural tourism and what problems rural tourism has encountered and to enhance public awareness. Secondly, training courses to raise skills of not only operators of rural tourism, but coordinators and instructors should be implemented.

\section{References}

[1] Carlzon, Y., Moments of Truth. Ballinger Pub Co.: Cambridge, Mass, 1987.

[2] Haines, M. \& Davies, R., Diversifying the Farm Business: A Practical Guide to the Opportunities and Constraints, BSP Professional Books: Oxford, 1987.

[3] Hall, D., Roberts, L., \& Mitchell, M., New Directions in Rural Tourism. Ashgate: Hants, 2003.

[4] Hall, D., Kirkpatrick, I., \& Mitchell, M., Rural Tourism and Sustainable Business, Channel View Publications: Clevedon, 2004.

[5] OECD, Niche Markets and Rural Development, OECD: Paris, 1995.

[6] OECD, Niche Markets as a Rural Development Strategy, OECD: Paris, 1995.

[7] Ohe, Y., Farm pluriactivity and farmland preservation: a perspective on evaluating multifunctionality from mountainous Hiroshima, Japan. Japanese Journal of Rural Economics, 3, pp.36-50, 2001.

[8] Ohe, Y., Evaluating household leisure behaviour of rural tourism in Japan. CD-ROM Contributed Paper Session 1, Xth European Congress of Agricultural Economists, Zaragoza, 2002.

[9] Ohe, Y., Economics of Farm and Rural Diversification (in Japanese). Association of Agriculture and Forestry Statistics: Tokyo, pp.27-46, 2003.

[10] Ohe, Y., The impact of rural road building on pick-your-own fruit farming in Gunma, Japan. Japanese Journal of Tourism Studies, 4, pp.13-25, 2005.

[11] Ohe, Y., Multifunctionality and rural tourism: a perspective on farm diversification. Journal of International Farm Management, 4(1), pp.1-23, 2007.

[12] Ohe, Y., Impact of Rural Tourism Operated by Retiree Farmers on Multifunctionality: Evidence from Chiba, Japan. Asian Pacific Journal of Tourism Research, 13(4), 2008 (in press).

[13] Page, S. J. \& Getz, D., The Business of Rural Tourism: International Perspectives, International Thompson Business Press: London, 1997.

[14] Sharpley, R., Tourism \& Leisure in the Countryside 2nd Edition, ELM Publications: Huntingdon, pp.73-80, 1996.

[15] Slee, B., Alternative Farm Enterprises 2nd Edition, Farming Press Ltd.: Ipswich, 1989.

[16] Tsutsumi, M., Women and Families in Rural Japan, Tsukuba-Shobo: Tokyo, 2000. 